UDC 811.163.41’373.7

https://doi.org/10.18485/ms_zmsfi1.2020.63.1.8

Изворни научни рад

Првослав Радић

\title{
ИЗ СРПСКЕ ФРАЗЕОЛОГИЈЕ: (ВИДЕТИ) ЧИЈА МАЈКА ЦРНУ ВУНУ ПРЕДЕ Лингвокултуролошки приступ
}

Прилог представља покушај да се протумачи израз (видети $u$ ) чија мајка ирну вуну upede. Анализа показује да се у дубљој семантичкој структури израза вероватно налази представа везана за етнички разнородно сточарско балканско становништво, обично обједињено именом „власи”, које је у изразу заступљено кроз метонимију - 'они који преду црну вуну, који носе црну вунену одећу'. Због свог номадског начина живота, ово становништво је код околног, стално настањеног и/или мање покретљивог становништва остављало низ представа и предрасуда, пре свега о својој несталној природи. У том контексту посматрано, израз се лако могао свести на значење 'онај ко је непоуздан, неверан', па, у одређеним контекстима, и 'издајник'.

Кључне речи: српски језик, Власи, миграције, црна вуна, мотив неверства, митологија, етнопсихологија, фолклористика.

The paper seeks to interpret the expression (videti) čija majka crnu vunu prede-lit. (to see) whose mother spins black wool. The analysis demonstrates that the deeper semantic structure of the expression is probably underlain by an image associated with the ethnically heterogeneous livestock breeding population of the Balkans, commonly referred to as the "vlasi" (cf. Vlachs). In this particular expression, they are referred to through metonymy - 'those who spin black wool, those who wear black woollen clothes'. Among the neighbouring permanently settled and less mobile communities, their nomadic lifestyle gave rise to many preconceptions and prejudices, primarily associated with their allegedly erratic and inconsistent nature. In this context, the meaning of the expression could easily be encapsulated as follows: 'an unreliable, unfaithful person', and in some contexts even as 'a traitor'.

Key words: Serb language, Vlachs, migrations, black wool, motif of unfaithfulness, mythology, ethnopsychology, folklore studies.

1. Општи приступ. Ношење црне одеће (,црнине”) и данас је у српском народу најпре знак жалости и ожалошћености, за шта има небројено примера у различитим изворима и у прошлости и у садашњости. ${ }^{1}$ Ношење црнине има нарочиту тежину када је знак родитељске жалости за изгубљеним дететом, посебно мајчине. Тако и распрострањен израз у српском народу - (видетиu) чија мајка ирну вуну йреде $e^{2}$ на први поглед упућује на овакав контекст и заправо као да нуди незаобилазно, метонимијско значење: '(видети) ${ }^{3}$ ко ће настрадати, погинути, тј. чија ће мајка бити у жалости’. Већ је уочено да је помињање мајке у оваквим изразима, „у клетви, прекору, жаљењу и сл.”,

\footnotetext{
${ }^{1}$ Једна епска песма, нпр., каже: „Да онога јунака на Косову не бјеше, / Ваше би се владике [“жене'] црна руха наносиле” (Богишић 1878: 45).

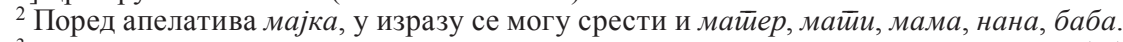

${ }^{3}$ Исп. нека од значења глагола вӥдейи у РСАНУ: 'запазити, запажати, закључи(ва)ти' (2б); ‘искусити, уверити се’ (3); ‘разуме(ва)ти, схватити, схватати, бити јасно’ (8).

${ }^{4}$ Уз овакав опис М. Стевановић 1983 (: мајка) наводи примере: „Аге Турци, жалосна ви мајка”; „Јунак добар ма образа нема, / превари се кукала му мајка”. Наравно, има и примера,
} 
уобичајено, па и једна пословица каже: „Junačka majka prva zaplače” (DANIČÍ́ 1996: 40), а друга, опет, вели: „Бјежанова мајка пјева, а Стојанова плаче” (КАРАџић 1975a: 14), што све може бити део ширег антрополошког миљеа, с могућим траговима матријархата. Кад је реч о црнини као симболу ожалошћености, она би се у анализираном изразу могла, дакле, довести у везу с црном вуном, па PMC (1: вӱна) израз йресиии црну вуну (коме) тумачи са 'приправљати црно рухо као знак блиске смрти’, док фразеолошки речник Т. Миленковић (2006: вуна) уз ирресиии ирну вуну даје унеколико померено значење - ‘бити у жалости'. Занимљиво је да су древним митским временима познате обредне представе жртвовања човека који је за ту прилику одевен у црну овчију кожу, док обред изводе људи обучени у бело руно (исп. GREVS 2008: 503).

Но, и изван појмова везаних за црнину и жалост, одавно је позната у нашој и сродним културама митолошка вредност појмова везаних за вуну, преслицу, пређу и предење, те бело и црно предиво (тј. конац), где доминиpajy судбинска предсказања везана за живот и смрт. ${ }^{5}$ Три грчке мојре ( $\mu$ огра)), на пример, које су представљале судбинско божанство, управо су се бавиле предењем (ЗЕчевит 1981: 81-82; GREVs 2008: 48, 184). Ова божанства (у нас позната као виле-суђаје, суђенице и сл.), које још Хомер назива прељама, лунарна су божанства и одређују судбину новорођенчета и код данашњих балканских сточара (Антонијевић 1982: 168). У западној Бугарској и Македонији оне преду или размотавају клупко пређе и судбински управљају нитима живота новорођенчета (СМ: преслица, суђенице, исп. РММ: наречници), а оваквим митолошким представама одликују се и други словенски народи. Зато је вуна као обредни предмет и знак везе с подземним светом, елеменат култа мртвих (ЧАЈКАновић 1985: 154-157, исп. фус. 5). ${ }^{6}$ Предања о црном овну (нпр. код Влаха, ВАлГАнд 1997: 108) који повремено излази из језера, вероватно представљајући својеврсну митолошку везу између овог и оног света, могла би ићи у прилог оваквим веровањима, иако је шире познато да се те митолошке црте приписују и другим црним животињама (нпр. коњу, псу). У том смислу привлачи пажњу и један мотив у народној причи из југозападне Бугарске који говори о старој баби из планине, ткаљи, која метафорички представља дан и ноћ - када тка белу вуну настаје дан, а када тка црну настаје ноћ (Видовски 2000: 253). Итд.

иако ређих, с друге стране ове вредносне скале, попут „Доби блага, весела му мајка” (Богишић 1878: 305).

${ }^{5}$ Исп. „Nesreća / Nevolja tanko prede” (DANIčić 1996: 78), или шире познато: „Где је танко, ту се кида”. (Можда је у вези с тим поморавска пословица: „Танкопрёља кроз плоิт стреิља”, П. Р.) Овде се, наравно, може јавити и низ другачијих значења. У вези с предењем и кудељом Д. Мршевић-Радовић (1987: 127) анализира израз „Другу кудељу прести” (“применити друга, оштрија средства').

6 У MAтEŠIĆ 1982, где не налазимо анализирани израз, бележимо ìmati vünu у значењу ‘бојати се', што се јавља и у више других извора (исп. наслов збирке песама Г. Ђога Вунена времена). Једна међу Србијанцима и данас популарна песма на тему Великог рата има стих: „Дошо Шваба до Земуна, од Земуна вуна, вуна!” (исп. савр. жарг. еквивалент чуйаво). Израз вуна кићо! (/ вуна байо!) (разг. 'страх, прпа, зорт', РСЈ: вӱна) забележио сам и у једној шаљивој причи из Поморавља, у којој ђаво у вези с неком опкладом због које треба да скочи с велике висине - пошто је од супарника чуо овај израз (вуна кићо!) - скаче у амбис помисливши да је доле вуна те да тако неће погинути. Мотив скакања у маглу с веровањем да је то вуна бележи и Г. Елезовић (1932: мудрйло). 
Ипак, и поред присуства низа постојаних митолошких симбола везаних за вуну, црну боју и смрт, чини се да су они недовољни за јасно семантичко представљање израза (видейи) чија мајка ирну вуну йреде. Упркос томе што на први поглед изгледа прихватљиво тумачење везано за могућу погибију детета (у ратничко-патријархалном друштву обично сина), те с тим у вези и мајчину ожалошћеност исказану ношењем црне одеће, чини се да је то објашњење мањкаво. Забуну најпре уноси чињеница да се овај израз углавном јавља уз, унеколико претећи наглашен, глагол видети $u$ у футуру (и то најчешће у 1. л. мн.), а не и глагол йресйu, како би се очекивало: $B$ и д е ћ е мо чија мајка ирну вуну й р ед $е$ ! Тако га у оквиру устаљених израза бележи, на пример, М. Радуновић (1996: 374) у Метохији, како је дат и уз поменуту одредницу у РМС („,екај док се само искупимо на граници, видећемо чија мајка црну вуну преде", Сл. Јовановић). Јер то онда у овако схваћеном изразу оставља једну озбиљну логичко-семантичку празнину, заправо чини га нејасним ако се његово значење своди на: 'видећемо чија мајка йреде (сйрема) црнину' (=

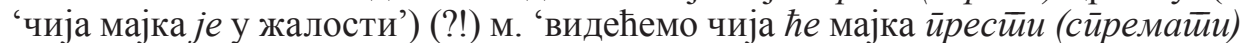
црнину' (односно: ‘чија мајка ће бийи у жалости'), - дакле, ако он треба да претпоставља мајчино спремање црнине пре дететове погибије, што би и с обичајног аспекта у нас било неприхватљиво. Додатна појашњена у правцу могуће футурске употребе презента глагола $\bar{u} р е с \bar{u} u$, односно неке врсте кондензације израза (нпр. према хипотетички старијем и такође десетерачком: чија $\hbar$-мајка црну вуну йрести), чини се да би у овом случају исто тако била неуверљива. Занимљиво је, даље, да овог израза изгледа нема у форми клетве (као нпр. у „Ега /да Бог да/ ти туре црну крпу на очи!”; „У црн повој да га повијеш! (Младој мајци)", ЂАповић 2009: 40, 49), где би га било природно очекивати ако полазимо од значења које га везује за смрт. Најзад, и само стављање мајчине жалости у центар, што с данашње тачке гледишта има пресудну улогу у поимању израза, прилично је различито у односу на представу мајке у свести старог, ратничко-патријархалног света овог поднебља (исп. Papazoglu 2007: 350-351). Довољно је, уосталом, сетити се мајке Јевросиме и њених савета упућених сину Марку (Урош и Мрњавчевићи), ${ }^{7}$ па препознати сасвим другачији миље од оног који је већина савременог света данас спремна да прихвати.

Ово, дакле, значи да се мора даље трагати за изворним значењем израза, заправо за путевима његове семантичке реконструкције, јер је врло вероватно да је примарно значење израза било другачије од оног које ми данас узимамо за готово општеприхватљиво, што није необично за лингвистички материјал ове врсте. Оно је свакако засновано у посве другачијем појмовно-метафоричном миљеу, временом културолошки избледелом и семантички оштећеном, па вероватно и накнадно укрштеном с другим, богатим врстама симболике које прате древну радњу предења, укључујући, наравно, и симболику везану за ношење црне одеће.

2. БАЛКАНСКИ ВЛАСИ: ОД ЕТНИЧКОГ ДО АПЕЛАТИВНОГ. У траГањУ за ИЗворним значењем овог израза не може се пренебрегнути једна важна семантичка

${ }^{7}$ Свој језгровито изнет морални савет Јевросима завршава речима: „Немој, сине, изгубити душе! / Боље ти је изгубити главу / него своју огр'јешити душу”. 
нит, а то је етнографски моменат повезан с доминантно сточарским, и то номадским привређивањем које одликује још давну прошлост Балкана (исп. PAPAZOGLu 2007: 362). Посебно нам у том смислу у центру пажње мора бити све оно што се тиче гајења црних оваца, те и предења одеће од такве вуне. За Влахе ${ }^{8}$ етнографи као једну од њихових одлика истичу израду одеће од вунене пређе ,prirodne boje ili obojene u crno” (Vlahović 1984: Cincari). Г. Bajганд, врстан познавалац влашког народа, као разлоге за бојење вуне („гаром”) преноси влашка веровања о мањој упадљивости оних који носе такву одећу, на пример у циљу њиховог лакшег скривања, уза шта иде и хигијенски разлог, заштита од гамади (ВАлгАнд 1997: 87). Постоји читаво богатство етнографских сведочења о овој врло покретној (доминантно романској) балканској етничкој групи, која је посебно неговала врсту црних оваца, дакле и користила црну вуну у домаћој радиности. Преносећи вредна етнографска запажања М. Ђ. Милићевића, Речник ЈАЗУ међу својим одредницама доноси и етноним Црновунац: ,pastir koji drži samo crne ovce, tako prozvan po crnoj vuni, koju ima od ńih. u Srbiji po ńekim krajevima [...] Crnovunci sa svojim stadima žive leti na planini, a zimi slaze u doline k Beloj Palanci, ka Prokupl̦u i daḷe niz Moravu, gde nađu sena za svoju stoku. Crnovunci jedni su po narodnosti Grci, a drugi su Cincari. Crnovunci se zovu po crnim ovcama svojim; jer u stadima ńihovim ovce su mahom gal̦e. Bele ovce po ńihovom mišl̦eńu slabije su od ovaca crnih za ovu klimu... Borave sa ženama i decom po planini: u planini se rađaju, u planini se žene i udaju, a u planini umiru i sarańuju se" (RJAZU: Crnòvunac). ${ }^{9}$ Дакле, већ M. Ђ. Милићевић у нас указује на то да су међу овим социјалним скупинама поред говорника романског учествовали и говорници грчкога језика. И потоња етнографска литература нуди податке „о номадима сточарима грчког говорног језика, називајући их Ашанима или Црновунцима” (Антонијевић 1982: 15), познатим и под именом Саракачани / Каракачани. ${ }^{10}$

Анализирајући „сточарску влашку етничку масу” на Балкану, и Д. Антонијевић (1982: 20) издваја две потпуно различите скупине обележене, између осталог, и начином одевања - Карагуне (тј. оне који носе црне гуњеве) и Фаршериоте (који носе искључиво бела одела). Врста етнографске посебности, везана за гајење црних оваца, нашла је, тако, одраза и у етнониму за део влашке скупине која је одавно позната Балкану. Већ А. Фортис бележи да је претежно на потесу од Дунава до Солуна живело становништво под влашким

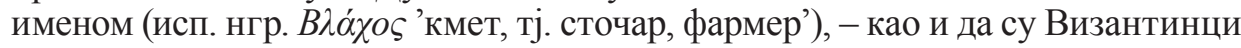

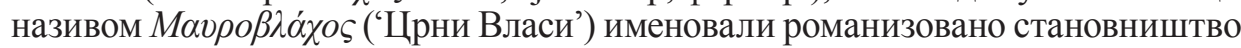

\footnotetext{
8 Уобичајено тумачење овог облика полази од Walah, како су стари Германи називали расуте келтске скупине по планинама Грчке, Србије, Бугарске и Румуније (исп. Sкок: Vläh; ГАВЕЛА 1978: 81), а Власима су затим Словени називали балканске Романе и тамошње романизовано становништво (Vlahović 1984: Vlasi). Не треба изгубити из вида могуће семантичке укрштаје овог облика са словенским апелативом влас или теонимом Волос, тј. хтонским божанством стоке (исп. ЛомА 2002: 247), утолико пре што ни данашњим Власима из североисточне Србије нису непознате представе о влашкој косматости (SIкIміс́ 2002: 194).

9 Под окриљем влашког (цинцарског, аромунског / ароманског) етноса П. Влаховић наводи петнаест локалних, ужетериторијалних назива, међу којима и Каравунц̧е (VLAHOVIĆ 1984: Vlasi, исп. тур. kara 'црн').

${ }^{10} \mathrm{O}$ Саракачанима / Каракачанима или (Куцо) Власима и њиховој данас угроженој „влашкој црној овци”, посебно жилавој и отпорној врсти, најближем сроднику муфлона, в. IVANOV.
} 
јужног Балкана (Vlahović 1990: 145). Пандан овоме је назив Nigri Latini, како се ово становништво назива у Летопису попа Дукљанина (ЈиРечек 1981: 34). В. Караџић, пак, бележи да Влахе „народ даље к југу и западу зове Каравласи, а земљу њихову Каравлащка" (КАРАџић 1975б: Влӓх). ${ }^{11}$ За разлику од приморских крајева, у којима је такође био познат етникон Влах (нпр. у Дубровнику), Црним Власима / Мавровласима (исп. лат. Moroulachi) „звати су брђански пастирски Романи", а међу Србима су се за ово становништво усталили и етноними Црновунци и Црногууњци (СтАнолевић 2001: Власи и Мавровласи), свакако уз асоцијацију на њихову сточарску делатност и доминантну боју њихове ношње. ${ }^{12}$ У своје време Ј. Цвијић за Црновунце констатује да им је Копаоник „последња планина на северозападу”, након што су свој радијус кретања према западу битно сузили (Цвилић 2000а: 190), што ће остати као тенденција и у потоњим временима. ${ }^{13}$

Етноним Влах се, међутим, у процесима устаљивања социјалне стратификације међу балканским становништвом све више семантички разводњавао (исп. КАРАџић 1975б: Влӓх; РСАНУ: Влӓх; Sкок: Vläh), управо у складу с етнографским обележјима оваквих етничких група и социоекономском симболиком која их је пратила. ${ }^{14}$ Разумљиво је, стога, што се међу потоњим значењима све више издвајало апелативно 'сточар' (ДАничић 1975: влахь; Цвијић 2000а: 190), управо по најзначајнијој особини која је обједињавала добар део иначе разнородног балканског становништва, романског, шиптарског, словенског. То је уобичајена појава апелативизације етнонима, коју бележимо и у другим примерима (исп. Грк $\rightarrow$ 'трговац', Јеврејин $\rightarrow$ 'зеленаш', Циганин $\rightarrow$ 'музичар', Татарин $\rightarrow$ 'поштар'). Но, уз значење 'сточар, пастир', чија је конотација кадшто ишла у правцу пејоративности (нпр. по основи тежње „да се њихово сточарско занимање обележи као нешто ниже", СтАноЈевић 2001: Власи и Мавровласи), могла су ићи и нека друга, па Влах, на пример, у многим областима значи и Србин (или човек српског порекла), хришћанин, углавном православни, те и говорник српског језика (исп. РСАНУ: Влӓх; Sкок: Vläh). То указује на постојање старих српско-романских симбиотичких процеса на деловима Балкана, потврђених већ раним присуством влашких (романских) имена у српском ономастикону (исп. НовАКовит 1965: 188; ЈиРечЕк 1981: 34-35). ${ }^{15}$ Влах је, дакле, на Балкану временом постала доминантна

\footnotetext{
${ }^{11}$ Назив је делом турцизиран (исп. фус. 9) - в. РСАНУ: Кара̀влах / Ка̀равлах, Кара̀влашка̄ / Ка̀равлашка̄. Можда се у том контексту може тумачити и фолклористички стих „Kuku Vlasi, crni siromasi”, дат кроз једну анегдоту у Sікіміс́ 2002: 190.

12 На могућу везу страног Караг̄уни и домаћег Црновуничи, као својеврсног калка, указује већ Новаковић (1965: 187).

${ }^{13}$ Већ у наше време М. Златановић (1998) под одредницом Црнову́нции бележи: „некадашњи влашки сточари у Пчињи".

${ }^{14} \mathrm{O}$ етнониму Влах у западнојужнословенским и суседним областима в. у синтетичком прилогу М. Влаховић (VLAHOVIĆ 1990).

${ }^{15}$ Овакве повесне појаве треба разликовати од хрватске политичке акције (чије рецидиве бележимо и данас) спровођене у западним јужнословенским областима, која је имала за циљ потирање српског етничког имена „влашким”. О томе сведочи и једна савремена хрватска анегдота која једно од четири оцила са србијанскога грба, обично лаички тумачена као четири слова $C$ (које у латиници има вредност $Ц),-$ везује за Црновлахе (поред Црногораца, Цинцара и Цигана) (ОкUKA 2006: 301). У позадини тога је идеја негирања постојања српског
} 
социјална и економска (пастир номад), потом унеколико и религијска категорија, - уз наглашену представу о покретном карактеру овог становништва, без обзира на његову народност. Можда је израз „nad vlaškijem nije lonca” (DANIČIĆ 1996: 67), вероватно у значењу 'нема лонца до влашкога' (тј. 'нема бољег лонца од влашкога'), управо настао из потребе да се нагласи ова сточарска покретљивост „влашког” становништва кроз представу о издржљивости њиховог (млекарског) посуђа и оскудног покућства, које преносе на снажним коњима за време својих дугих путовања. На дужину њихових путовања кроз циклична номадска кретања можда указује и израз $v l a ̈ s ̌ k \bar{a}$ gödina, у значењy 'vrlo dugo vrijeme' (Дубровник, Прчањ, Херцеговина, REŠETAR 2010: 316$).{ }^{16}$

Не треба, најзад, превидети ни могуће својевремено успостављање једне врсте етнографске и културолошке опозиције између оних који су гајили црне и оних који су гајили беле овце, која је могла досезати и до митолошког односа између појмова бело и ирно. Под окриљем хришћанства то је нашло одраза и у појединим веровањима о односу између беле и црне овце (исп. ЂорЂЕвић 1958: 188). ${ }^{17}$ На другој страни, у међувремену је и само гајење црних оваца доживело пад и оне су постале реткост у балканском овчарству (в. фус. 10), одакле можда и срп. израз битии ирна овиа ${ }^{18}$ чија доследна паралела у

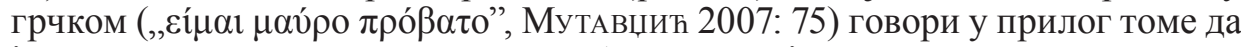
је у нас реч о калку према неком од балканских језика. То говори да и у вези с изразом (видейи) чија мајка ирну вуну иреде можда треба трагати за одговарајућим паралелама у осталим балканским језицима, ако не и даље, утолико пре што су „балкански Словени у области сточарства били под јаким утицајем балканских старинаца" (Будимир 1969: 166).

3. ИЗ БАЛКАНСКОГ ЕТНОПСИХОЛОШКОГ ИНВЕНТАРА: „НИ У ТИКВИ СУДА, НИ У ВлАху другА”. Напуштајући ову изузетно широку и разуђену тему, те задовољавајући се основном поставком о прилично јасној етнографској вези између делова влашког становништва и њихове црне вуне, црне одеће и сл., прелазим на питање које треба да код анализираног израза одгонетне присуство мање-више упозоравајуће па и претеће поруке везане за могућу злу срећу, удес, можда и својеврсну неподобност особе чија мајка ирну вуну ирреде. За то је потребно да завиримо у могуће етнопсихолошке, можда и карактеролошке представе које се везују за влашку етничку групу (исп. SIкIмIс́ 2002), па и за оне разнородне балканске заједнице које су због своје сточарске делатности,

народа и његове културне баштине западно од Дрине, негована још од Наполеонова времена (исп. нпр. Грујић 1909; Екмечић 1999: 41, 91, 132-133).

16 Уз опаску да је израз вероватно настао у католичкој средини, где се православци називају Власима, Решетар га тумачи тиме да се католицима „влашка” година чини дужом „budući da se završava više dana poslije katoličke” (2010: 316). Можда нису без значаја за ово питање епске представе о предугом периоду од Митрова до Ђурђева дана (до следеће године), пошто се хајдуци једва чекају поново састати (в. 3).

17 Другачији, иако по свему судећи такође култни однос према белој овци вероватно је садржан у хипок. лексеми свилору́нче ('девојчица светле косе'), коју сам забележио у поморавском крају.

18 Друго тумачење израза би могло бити у вези с обичајем да се међу домаћим животињама чува и једна црне боје, како би се стадо сачувало од урока (ЂорЂевић 1958: 188). 
углавном номадске природе, често бивале подвођене под општи назив „власи”. Јер, више аутора уочава да су „власи” (изгледа најпре „црни власи”) својим горштачким животом остављали утисак примитивности и дивљачности код околног становништва. Б. Курипешич 1530. године помиње у западној Србији „сточаре грубога и простог живота” (НовАковић 1965: 100), а још је романско становништво старих градова називало сав околни сеоски живаљ „црним власима”, тј. Морлацима (лат. Moroulachi), „гледајући на њега са висине и причајући о његовим свирепостима и дивљаштву језиве приче” (Цвијић 2000а: 172). Половином XIX столећа један немачки аутор бележи да су „Dalmatinci i Morloci [sic!] čitavi [...] poludivljaci, i gori su od Turaka, niti izlaze kud bez pušaka" (према MAmuzić 1978: 519). Очито, због тога у Далмацији „нико не прима назив Влах или Морлак и преноси га све даље на Исток према копну” (Цвијић 2000а: 173, исп. РСАНУ: Влӓх). Можда по тој основи и поједини фитоними из дубровачке околине као синонимне одредбе имају дивље и влащко, на пример gräh dìvlāk / vläškī gräh ('vrsta neukusnoga pasulja u mahuni', REŠETAR 2010: 317).

Својом сточарском покретљивошћу „власи” су код околног становништва свакако остављали и утисак несталности и променљивости, а у тим економским кретањима „нестална њихова природа - како пише Новаковић (1965: 32) - гони их много даље него што би потребно било”. О томе можда говори и израз „својевољни власи”, забележен у епској поезији („Скупићемо Влахе својевољне", Богишић 1878: 239). ${ }^{19}$ Биће да тај израз има везе и с чињеницом да су у старој српској држави током одређених периода влашки катуни „задржали неке елементе самосталне, унутрашње организације” (ШАРкић 1995: 40), и поред њиховог начелно зависног социјалног положаја. Историјски подаци говоре о племенима Влаха која су „остала на лицу места још од времена Михаила-Палеолога, независна и после турског освајања Епира" (Антонијевић 1982: 30). У вези с тим, има још један чинилац који је могао потпомоћи формирању негативних представа о Власима и њиховом менталитету код околних етничких група. Наиме, „Османлије су радо преузимали Влахе и у своју службу, где су као познаваоци места и домаћег језика с великим успехом били коришћени и као уходе [...] Војно организовани још у византијској, а касније и у српској држави, скренули су пажњу османлијских команданата на себе" (30, курз. П.Р.). Етнографска литература потцртава и економски значај, па и привилегије овог добростојећег друштвеног слоја у време турске владавине, нарочито до XVII столећа (VLAHOVIć 1984: Vlasi). Из оваквог миљеа међу околним становништвом, пре свега седелачким (нпр. земљорадничким), није било тешко црпсти уверење не само у „влашку” несталност него и непоузданост. ${ }^{20}$

19 У РМС: свӧјево̄љан / својѐво̄љан б. 'самовољан, својеглав, тврдоглав’, а исто и у РСЈ, с том разликом што се ово значење даје као примарно. Исп. и „Пераштани самовољни витезови” (Богишић 1878: 210), или Нушићево запажање о „разузданом и самовољном” становништву Дренице, које не поштује законе турске државе (Нушић 1902: 38). Стих „,samovoljan Turčin Vlah-Alija” помиње Скок у речничкој одредници (Sкок: Vläh).

20 Одрази оваквог односа према Власима можда су се препознавали и у односу према потоњој градској популацији овога народа, Цинцарима, те, нпр., према њиховој трговачкој предузимљивости, која је укључивала пословање и с Турцима и са Србима. Такву једну београдску цинцарску породицу описује Б. Пекић у роману Злайно руно. 
Свакако је управо таква представа о номадским „власима” и њиховом менталитету остала и у пословици „Ни у тикви суда, ни у Влаху друга”, за коју сакупљач између осталог бележи да код Ј. Мушкатировића стоји „, йостиојану [sic!], мјесто : у влаху" (КАРАџић 1975a: 224), док је у западнијим крајевима забележена варијанта ове пословице: „Ni u moru mire, ni u Vlahu vire" (Vlahović 1990: 147, исп. Sкок: Vläh). Српска фолклористика бележи више таквих пословица, а једна, пак, од њих у десетерачким стиховима каже: „О Турчине, за невољу куме! - / А ти Влаше, силом побратиме!” (КАРАџић 1975a: 244, исп. 282, 287). Логично је претпоставити да се тај наративни фолклоризам ширио из представа о менталитету влашке етничке групе ка другим, социокултурно блиским етносима, онако како се то дешавало и са самим термином Влах (в. 2). Тако се може разумети и паралелизам заступљен у још једној варијанти поменуте пословице: „Ni tikva sud, ni Srbljin drug” (DANIČIĆ 1996: 80). М. Будимир, исправљајући Караџића и указујући на поодмакао процес апелативизације етнонима Влах ${ }^{21}$ тумачи Караџићеву пословицу („Ни у тикви суда, ни у Влаху друга”) следећим речима: „Као што је тиква слаб и крхак суд, тако је сваки сточар, који иде са својом стоком тражећи бољу пашу, одсутан и непоуздан” (Будимир 1969: 164). Уз такву покретљивост и непоузданост ишла је по логици ствари и представа о слабој хришћанској побожности оваквих племена (исп. ЈовАновит 1990: 38; Sікіміс́ 2002: 188). Вероватно се, тако, у имену „влах” у балканским језицима временом развила негативна конотација (исп. у епском стиху „При себ’ руке, чобанино Влашка!", КАРАџић 1975б: чо̀банина), која је потом лако могла задирати и у остале лексеме из ове социокултурне сфере (исп. управо лексему чобанин). Негативне конотације, наравно, нису могле бити поштеђене ни „влашке” жене, према којима су се временом такође формирале негативне предрасуде, саображене природи адресата (исп. SIкIміс́ 2002: 191). ${ }^{22}$

Није немогуће да се такав став према „власима” у неким периодима укрстио и с негативним односом према властима недоступним или тешко доступним људима, али и од власти одметнутим разбојницима и хајдуцима, што као правну материју обрађују већ српски средњовековни законици. Хајдучија, уз сељачко јатаковање, временски омеђена већ митским Ђурђевданом (,хајдучким састанком”) и Митровданом (,хајдучким растанком”), имала је традицију у брдовитим, тешко приступачним пределима, али и

${ }^{21}$ Ово је дато уз опаску „да је овде реч о именици, а не о имену Влах”: Влах $\rightarrow$ влах 'сточар, пастир' (Будимир 1969: 164, исп. 156).

22 За примере из бугарске фолклористике в. код Б. Сикимић на истом месту, а сличан однос према Влахињама забележен је и на македонском терену. Македонска пословица „Влашка жена (е како) планинска коза” (из сакупљачког опуса К. Шапкарева) тумачила се међу македонским фолклористима овако: „Моралната неразвиеност на Влаинките, Каракачанките, што живеат номадски живот по планините” (ПоленАковиќ - ПЕнушлиски 1954: 26, исп. 282). Претпостављам да се овде коза узима као симбол промискуитета, јер се и у србијанским крајевима у различитим шаљивим изразима узима коза као пример животиње која не скрива (тј. не може скрити) свој полни орган. Можда се та идеја нашла и у основи пословице „Сijem se ovca srami, tijem se koza diči” (DANIČı́ 1996: 13, исп. ЂорЂевић 1958: 193-197). За анализу израза је то утолико важно што је по овој основи могао стећи негативну конотацију и „влашки син”. Исп. могућу паралелу према изразу курвин син, чији се постанак у нас понегде погрешно везује за утицај енглеског језика. 
„влашким елементом протканим или засићеним” (Дворниковић 2000: 790), с чим можда треба довести у везу и оно предање које тамну боју влашке одеће види као заштитни чинилац (в. 2). Неке фолклористичко-топографске подударности, заправо поклапања између некадашње традиције хајдуковања и назива појединих планина, као да иду у прилог томе. Тако је Влашић у епској поезији „хајдучка планина” (али је таква и Романија!), чиме се влашко име проширило на различите ситуације и представе о „власима”. Битно је за ову тему потцртати неповерење према таквим групама и појединцима, као и тежњу да се они изопште из друштва чије моралне норме не прихватају. Управо ће се тиме одликовати и законске одредбе из новијих времена, при чему се у једној од њих (распис из Протокола Шабачког магистрата, 1808), поред оштрих казни које се предвиђају за село и сељане који помажу хајдуке, најпре каже следеће: „Оштро кметовом налажемо да од сада ако би који у хајдуке отишао, у тога вере нема, нити ће се на веру звати" (НовАковић 1965: 200). ${ }^{23}$

Културолошка супротстављеност између појединих етничких или социјалних група која провејава из ових примера најпре је логичан резултат давноуспостављене, готово универзалне економске опозиције седелачко : номадско, о којој су и средњовековна правна акта водила рачуна у циљу очувања ратарске привреде. То је, на пример, исказано законском одредбом из Дечанске повеље: „срьбинь да се не жени оу власьхь” (ДАничић 1975: 132), заправо „сељак ратар да се не жени ћерју несталних пастира”, како то појашњава Новаковић (1965: 40). Те две социоекономске категорије, обе значајне за привреду једне земље, временом су се, кроз борбу земљорадника за што више обрадивих површина и сточара за што више слободних пашњака, међусобно почеле супротстављати (исп. Цвијић 2000а: 205, 207). На етнопсихолошком плану, седелачко становништво (у повељама често „земљани”, „земљани људи”) је „влахе”, по много чему слободније становништво, склоно номадском животу, сматрало себи супротстављеним. ${ }^{24}$ Вредна је пажње чињеница што се у једном периоду успостављена опозиција седелачко (тежачко) : номадско (сточарско) почела преносити и на опозицију српско (/ „српско”) : влашко (/,влашко”). О томе нам говори једно запажање М. Ђ. Милићевића да су се у појединим периодима, који су седелачком становништву доносили повољније услове за живот, многи од ових номада желели негде стално настанити и постати „Срби” (исп. „Да будемо и ми Срби”, према НовАковић 1965: 33), како се тумачи и постепено ишчезавање номадских катуна и њихово претварање у села већ од XV столећа (43-45). Тежња да се буде

${ }^{23}$ Није чудно што се управо у овој теми као кључна реч нашла вера (нпр. въра 'fides, која се даде да се не би требало бојати за што', ДАничић 1975; исп. лат. vērus 'истински, истинит, прави'), тако често присутна у српској епици, но прихваћена и у делу несловенских балканских народа. О улози овог етнолошко-митолошког термина у српским формама заклињања в. Грковић-Мејџор 2016: 228-233.

${ }^{24}$ Неповерење између ратара и сточара могле су повећавати и поједине средњовековне законске одредбе, као она која говори о обавези земљорадничких села да пруже конак (,престајање”) „власима” који се крећу од једног пасишта до другог. Економску тежину те одредбе потврђује и чињеница да су правна акта у исто време забрањивала другим сточарима да у потоњем периоду коначе у истим селима (ШАРкић 1995: 39-40). 
„влах”, замењена је, дакле, у каснијим, другачијим друштвеноповесним временима жељом да се буде ,србин”.

Из квалификација које говоре о несталности и непоузданости „влашког” становништва лако се могла издвојити, па у оквиру овог миљеа и митологизовати, и квалификација „влашке” превртљивости, потворности и лукавства, можда управо садржана и у старом дубровачком изразу Koju vunu češljaš? (DANIČIĆ 1996: 47). Истраживачи препознају трагове овог етнопсихолошког модела међу балканским становништвом и у новијим временима. Тако, Ј. Цвијић на занимљив начин, чини се и са симпатијама, представља једну српску, тзв. старовлашку или ерску етничку групу, која се претежно бави сточарством, но која чува и склоност ка хајдучији. Њихове припаднике, за које аутор, иначе, бележи да их одликује мушка и женска ношња од црне вуне, аутор види обично као виспрене у говору, живога духа, досетљиве, склоне надмудривањима и шеретлуку, а за најдаровитије констатује „дубоко лукавство и мудрост" (Цвилић 2000б: 284). Лако се може запазити да је то готово све оно што одликује фолклорни лик Ере, главног јунака многих шаљивих српских прича. Ослањајући се на своју истраживачку интуицију, Цвијић ће најзад запитати: „Да нема у овим особинама и у надмудривању нечега романскога?" (284). ${ }^{25}$ Но, још је у старобалканском илирском карактеру, паралелно с грубим и насилним, ишло лукавство и смисао за превару, „што је сасвим у стилу брђанског племеника", чије карактерне одлике поједини истраживачи препознају и у Одисеју (Дворниковић 2000: 296). На другој страни, та међусобна изукрштаност различитих карактеристика добро је представљена кроз општепознате чињенице да се, на пример, појам неверства и лукавства у балканској фолклористици везивао и за Грке (исп. „Не веруј Грцима ни кад ти дарове носе”) и за Латине (нпр. у српској епици: „Латини су старе варалице”, „Латинине невјерни јуначе”), вероватно и по основи међусобног културолошког сусретања и прожимања, али и супротстављања. А овај модел се потом лако могао ланчано ширити на узајамне односе међу другим народима у овој области, чак и међу деловима истог народа, верски или по другим основама подељеног (нпр. Грци - Власи - Срби vs. Латини - Романи - Хрвати и др.). Као да нам о томе, управо по основи успостављања културолошке опозиције између „нашег колективног МИ“ и ОН-И, добро сведочи и општепознати израз на нашим просторима: „да се Власи не досете!”.

Није, дакле, тешко из „влашког” етнографског и етнопсихолошког миљеа, који у свом развојном спектру започиње сировим и горштачким, а врхуни превртљивошћу и лукавством, изгранати код других ${ }^{26}$ и народску представу о неповерењу у „влахе”, па и о издаји и издајницима који се регрутују међу њима. Можда то није далеко, на пример, од оног дела српског митолошког корпуса из кога потиче и Лазарева сумња у неверство свога зета Милоша Обилића пред одсудни Косовски бој (Кнежева вечера), - потпомогнута изгледа управо фолклористичким представама о горштачком пореклу Мило-

${ }^{25}$ Међу српским пословицама о мудрости налазе се и оне у којима се лексеме Латинин и лисица јављају напоредо у синонимним вредностима, исп. „Мудар као Латинин” / „Мудар ка' и лисИца" (КАРАџИЋ 1975a: 183).

${ }^{26}$ Вероватно је управо тај миље диктирао присуство „нашег МИ” (vs. ОН-И), исказано обликом 1. л. множине (видећемо) у анализираном изразу. 
шеву, заједно с подругљивим односом према његовом ниском роду. ${ }^{27}$ Заиста, у представљању Милошева историјског лика истраживачи обично указују на то да се не зна одакле је био родом, те да вероватно није био великаш, а у прилог његовом горштачком пореклу свакако иде и легенда о погрдној форми његовог презимена Кобилић, Кобиловић (нпр. МARETí́ 1966: 201). ${ }^{28}$ Без упуштања у трагање за изворним Милошевим презименом и етимологијом тог облика, јасно је да се у делу народних веровања била укоренила чврста семантичка веза између презимена Кобилић и апелатива кобила, што заправо на дубљем плану упућује на древну митску, како је добро уочено и кентаурску природу овог лика (ЧАЈкАновић 1994: 211). То најбоље потврђује епска песма Сестра Леке капетана, у којој девојка Росанда одбија Милоша као просца и своме брату с прекором каже: „Јеси л' чуо ђе причају људи, / ђе ј’ Милоша кобила родила [...] / кобила га сисом одојила". ${ }^{29}$ Овакво виђење Милоша као да потврђује идеју о горштачкој природи његовој, што произилази и из појединих етимологисања која Милошево име доводе у везу с „преудешеним арбанским обликом Малощ-Малещ’', тј. 'Брђанин' (БудимиР 1969: 167). Ово можда наводи управо на његово сточарско, „влашко” порекло, у прилог чему иде и помињање његовог чобанског занимања у фолклористици (исп. Лома 2002: 226), што у исто време отвара тему везивања овог лика за баштину различитих народности тадашњег Балкана, укључујући и шиптарску (исп. ЧАлкАновић 1994: 210-220). Можда, дакле, у поетичкој визури и тај социјални елеменат подразумева могућу Милошеву несталност, осуђену у делу високих српских друштвених слојева, иако управо она кроз Милошево лукавство, захваљујући коме убија турског султана, оставља вечни помен у Срба, као симбол отпора, храбрости и пожртвованости. То је, чини се, добрим делом у сагласју и с митолошким довођењем Милошевим у везу с Месецом, симболом променљивости и несталности (исп. NoDILO 1981: 625).

То, наравно, није једини лик у српској епици који се може тако анализирати. Један други Милош - Милош Војиновић, иако је у песми представљен као сестрић цара Душана и, како ће песма на крају показати, његов поуздан ослонац (Женидба Душанова), такође ће најпре бити предмет царевог неповерења, чак беса због наводно бахате нарави његових сестрића, два Војиновића, која се надалеко била прочула. Иако је овај Милош представљен као јунак племенита рода, песма јасно показује да је и он чобанин („Милош-чобанин”), да долази из планине од свог небројеног стада, ${ }^{30}$ заправо да припада

${ }^{27}$ На другој страни, Милош (вариј. Мило, Мило(и)н, Билиш) Обилић (Кабле, Коболи, Комнен, Кобила, Кобљак, Кобиловић, Кобилић, Ковиљић) се у појединим споменицима од XV столећа помиње као српски племић (Поповић 1977: 57, в. и Прилози 155-202).

28 У Поморављу се, нпр., кроз шалу понекад говори о детету (погр. койилейу) којег је родила и отхранила кобила, при чему се чува и веровање о хранљивости овог млека (в. фус. 29). Иначе, Койилић се у песмама јавља као варијанта Милошева презимена Кобилић, а с тим у вези је свакако и веровање да је Милош напуштено дете које је отхранила кобила (исп. ЛомА 2002: 249).

${ }^{29}$ У овом фолклористичком детаљу несумњиво имамо трагове познате старобалканске галактофагије, исхране млеком и млечним производима, укључујући и оне кобиљег порекла (исп. PAPAzoglu 2007: 301), што није тешко претпоставити и за потоње Влахе, познате и по гајењу коња.

${ }^{30}$ Оваква поставка, која српску властелу види и у дубоко сточарском економском амбијенту, бар у одређеним повесним периодима, одговара реалном стању ствари (исп. ЛомА 2002: 95-96). 
„влашком” културном миљеу. Милош се неопажено придружује царевој свадбеној поворци прерушен у „ирног̄ Бугарина” од „земље Каравлашке” (!), који потворно преко своје сјајне витешке одеће носи бугар-кабаницу - „бугарску кабаницу од црне вуне, да га у сватовима не би познали" (ЛомА 2002: 247 , исп. 2). ${ }^{31}$ Круг се, дакле, затвара у тачки стереотипа у којој се горштачко спаја и преплиће с непоузданим, нестално с потворним и неверним. Народни певач ће, ипак, мудрост и лукавство и једног и другог оклеветаног витеза (пре)усмерити према њиховим високоморалним циљевима, стављајући их у функцију оданости и верности владару и држави.

4. УМЕСто зАКљУчкА. Из досадашњег излагања није тешко закључити да видетии чија мајка ирну вуну йреде значи 'видети, открити онога ко је другачији, ко се издваја и разликује, дакле, ко је отпадник, тиме и неверан и могући издајник'. А појам издајства је један од главних елемената архетипске поставке митолошког виђења света, како, на пример, у новозаветној визури судбинског страдања Христова, или Лазарева страдања на Косову пољу, тако и многих других митова у повести људскога рода. Чини се да је овај (вероватно не случајно десетерачки) израз истргнут из једног ратничко-патријархалног миљеа давних времена, обележен својеврсним кодексом у коме су вера (поверење) и верност ${ }^{32}$ имале тежину какву савремени човек све теже поима. Зато се чини да израз (видет̄u) чија мајка чрну вуну йреде, будући да је приближен српској фолклористици, има заправо своју паралелу у изразу: (видейи) /ко је в(j)ера а/ ко је нев(j)ера, тако добро познатом српској епској поезији. Наравно, сам појам неверства је често друштвеноповесно условљен и семантички растегљив, склон лутању и ланчаном измештању из народа у народ, из културе у културу. Није, стога, немогуће ни да је анализирани израз најпре потекао у „влашкој” средини, где је, на пример, величао горштачку, отпорну и издржљиву природу њених припадника, ${ }^{33}$ насупрот равничарском амбијенту и мекој земљи, која, како је већ античком свету било познато, ствара меке људе и поданике (исп. Херодотова Историја, 418). На елементе тог архетипа указују делови српске епике, на пример познати сукоб Марка и Мусе, који певач представља кроз различите социјалне оквире у којима су дошли на свет - један у дворцу, повијан свилом, а други код оваца, повијан црном (!) вуненом струком (Марко Краљевић и Муса Кесеџија). Но,

${ }^{31}$ РСАНУ у дефинисању бугар-кабанице не помиње њену (црну) боју, али привлачи пажњу одредница Бӱгарин 2, где се даје покр. значење 'Каравлах’ (Босна) (исп. фус. 11). Скреће пажњу и пример из RJAZU, где је у контексту значења глагола bügariti 2 ('zapijevati, pjevati što žalosno') та радња представљена и присуством црнине: „Matere i sve žene od pobjenijeh bugareći crnijem ruhom pokrivene otidoše k paši”.

${ }^{32}$ На тај изворно витешки миље указују средњовековни српски законици у којима је „невера (издаја) [...] кривично дело кога чини властела” (ШАркик 1995: 99).

33 Да ли по основи неких реалних значењских трагова или, пак, по основи семантичке мутације и губљења језичког осећања за изворно значење израза, тек једно такво, афирмативно значење, саображено савременом политичком тренутку, забележио сам у новинском тексту: „Tako se priča o vozovima pretvara u političku priču u kojoj će, a to se već naslućuje, protokom vremena postati važnije čija majka crnu vunu prede [тј. ко има кога у власти!], no da li je neko uz masnu proviziju, mimo zakonske procedure, pazario robu koja ne vredi novca isplaćenog za nju" (ŽARKOVIĆ 2005). 
не треба превидети да су управо горштачке и хајдучке особине приписане Марку у једној другој епској песми (Орање Марка Краљевића), у којој он као национални јунак „оре друмове” уместо њива и на њима сачекује Турке, којима се свети и пљачка их. Није искључено да је израз „орати друмове”, у значењу 'бавити се хајдучијом, пљачкати путнике и сл.' (исп. и фонетску

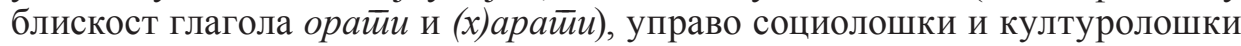
пандан ономе који гласи „орати њиву”, поново кроз опозицију г̄орщйиачко : земљорадничко. На то нас подсећа Б. Нушић, кад у једном тексту пише о косовским Шиптарима „који се радије прихватају пушке те 'ору друмове' него рала да њиме запарају плодну њиву” (Нушић 1902: 52). ${ }^{34}$

Тако је и израз (видет̄u) чија мајка црну вуну йреде, као несумњиво стара фолклорна творевина, резултат културолошких процеса у сложеном балканском етничком мозаику у којем је у исто време исказана и тежња за разноликим симбиотичким повезивањима и слагањима (исп. нпр. превођење етнонима Влах у Србин кроз апелативизацију Влах $\rightarrow$ сточар, пастир). Иако модел разгранате метонимичности овог и сличних израза захтева посебну стилистичку анализу, на семантичком плану је у овом случају јасно повезано и заокружено више узастопних, ланчано остварених нивоа:

(1) Жена (мајка) која преде црну вуну је „влахиња”, и

(2) њено дете (заправо син) је, дакле, ,влах”, али

(3) „влахињих син” је као такав могућа „невера", јер су

(4) „власи” нестални и непоуздани, склони да изневере.

Тиме је заправо вишеструко метонимијски, кроз један етнографско-фолклористички контекст, уместо неверник, издајник речено заобилазно: онај који припада „влашком” друштвеном миљеу, који је „влах”, те још скровитије (кроз презентски квалификатив) - онај чија мајка „црну вуну преде”. Ту је заправо употребљена врста стилске фигуре која подразумева продор у дубљи смисао уз загонетање и одгонетање загонетнутог, што није реткост у српској фолклористици. ${ }^{35}$ Анализирани израз се, несумњиво, на исто такав, сложен начин кроз дужи временски период развијао, гранао и дограђивао, а потом с блеђењем друштвеноекономске матрице на којој је узникао, па и ратничко-патријархалног миљеа у који се лако примао, започео своје неизбежно повлачење. То повлачење, како у језику често бива, исказивало се

${ }^{34}$ Израз „орати друмове”, који је вероватно у међувремену развио метафоричку, па и жаргонску димензију, представља занимљив пример како се кроз његову накнадну буквализацију остваривао и комични ефекат поменуте епске песме, данас, наравно, све мање појмљив као такав. Иначе, израз, можда услед недовољног броја потврда, није забележен у РСАНУ, у чији корпус је ушло и ово Нушићево дело.

35 Поента читаве једне шаљиве народне приче сведена је, нпр., на одгонетање метонимијски дате родбинске везе мушкарца и жене који иду путем (,овому мати [је] моје матере свекрва", БовАн 1989: 211), а међу бројним кратким фолклористичким формама бележимо и оне попут „Намјерио се на рутав нос” (КАРАџић 1975a: 189) / „Видећеш ти некоме рутав нос!” ('наћи ће се и од тебе неко јачи') (РАдуновић 1996: 374), „Гологлав мајке да останеш!” ('Да му умре мајка па да иде гологлав, како је обичај’) (БовАн 1989: 241), „Капата да ти опустеје!” (ЂАповић 2009: 37-38) и др. Оваквих појава има и у савременом жаргону, нпр. „Не закопчавам се ја на леђа!' ('Не носим лудачку кошуљу, тј. нисам луд, наиван'). Овакви модели језичке херметичности понекад се приближавају механизмима који се јављају у тзв. тајним језицима Балкана, чиме заправо упућују и на трагове неке врсте жаргонизама прошлих времена. 
кроз потискивање и губљење основног значења, те готово произвољно калемљење нових, па је резултат тога процеса данас заправо секундарно, сурогат значење израза, сведено на везу с представом о црној вуни и црној одећи као знаку жалости.

\section{ЦИТИРАНА ЛИТЕРАТУРА}

Антонијевић, Драгослав. Обреди и обичаји балканских сйочара. Београд: Српска академија наука и уметности - Балканолошки институт, 1982.

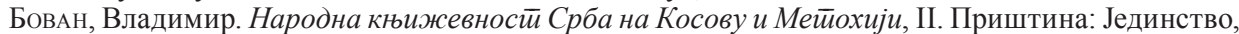
1989.

Богишић, В. Народне пјесме из старијих, највише приморских записа, 1. Гласник Срйског̄ ученог̄ друшимива 10 (1878): Х-430.

Будимир, Милан. Са балканских истиочника. Београд: Српска књижевна задруга, 1969.

ВАЈгАнд, Густав. Аромуни, II. Београд: Српско-цинцарско друштво „Луњина”, 1997.

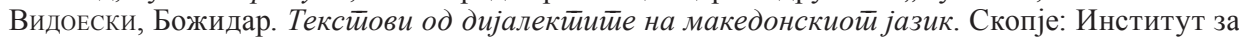
македонски јазик „Крсте Мисирков”, 2000.

ГАвелА, Бранко. Предања и знања о стиаром Балкану. Београд: Нолит, 1978.

Грковић-Мєџџо, Јасмина. Обрасци заклињања у историјској перспективи: лингвистички и когнитивни увиди. Академске беседе, I (2016): 223-234.

Грулић, Радослав. Айолог̄ија срӣског̄а народа у Хрвайској и Славонији и њег̄ових г̄лавних обележја. Нови Сад: Штампарија учитељског деоничар. друштва „Натошевић”, 1909.

ДАничић, Ђ. Рјечник из књижевних сйарина срйских, 1. Београд, 1863. Београд: Вук Караџћ, 1975.

Дворниковић, Владимир. Каракӣеролог̄ија Југ̄ословена. Београд, 1939. Београд: Просвета, $2000^{2}$.

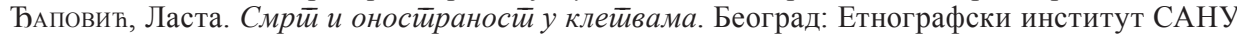
(посебна издања, књ. 66), 2009.

ЂорЂевић, Тих. Р. Природа у веровању и предању нашега народа, І. Срйски ейног̄рафски зборник LXXI (1958): 1-319.

ЕкмЕчић, Милорад. Оглледи из истиорије. Београд: Службени лист СРЈ, 1999.

ЕлЕзовић, Гл. Речник косовско-метохиског дијалекта, I. Срйски дијалекйолощки зборник IV (1932): XXIII-477.

ЗЕчевић, Слободан. Мийска бића срӣских йредаґа. Београд: „Вук Караџић” - Етнографски музеј, 1981.

Златановић, Момчило. Речник гоовора јужне Србије (йровиниијализми, дијалекӣизми, варваризми и др.). Врање: Учитељски факултет, 1998.

ЈиРечек, Константин. Истиорија Срба, II: Кулимурна истиорија (превео и допунио Ј. Радонић). Београд: Слово љубве, $1981^{2}$.

ЈовАновић, Јован М. Јужна Србија од краја ХVIII века до ослобођења. Београд, 1938. Београд: Танеси, 1990

КАРАџИћ, Вук Стеф. Срйске народне йословице и другее различне као оне у обичај узейе ријечи. Беч, 1849. Београд: Нолит, 1975a.

КАРАџић, Вук Стеф. Срйски рјечник исииумачен њемачкијем и лайинскијем ријечима. Беч, 1852. Београд: Нолит, 19756.

Лома, Александар. Пракосово. Словенски и индоевройски корени срйске ейике. Београд: Српска академија наука и уметности - Балканолошки институт - Центар за научна истраживања САНУ и Универзитета у Крагујевцу, 2002.

Миленковић, Тања. Идиоми у срйском језику. Алексинац: „Атеље 63”, 2006.

Мршевић-РАдовић, Драгана. Фразеолощке г̈лаг̆олско-именичке синйаг̄ме у савременом срйскохрвайском језику. Београд: Филолошки факултет Београдског универзитета, 1987.

МутАвџић, Предраг. Грчко-срисски речник идиома. Београд: Јасен, 2007.

Новаковић, Стојан. Село. Београд: Српска књижевна задруга, 1965.

Нушић, Бранислав. Косово. Ойис земле и народа, І. Нови Сад: Матица српска, 1902.

ПоленАковиќ, Харалампие, Кирил Пенушлиски (ред.). Македонски народни умотиворби, IV-1. Пословици. Скопје: Книгоиздателство „Кочо Рацин”, 1954. 


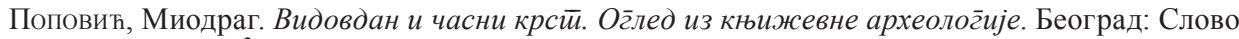
љубве, $1977^{2}$.

РАдуновић, Милорад. Остиала је реч. Срйске народне умойворине из Метиохије (Скупио, записао и приредио М. Радуновић). Београд: Григорије Божовић - Српска књижевна задруга, 1996.

PMМ: Речник на народнайа мит̄олог̄ија на Македониииее (ред. Т. Вражиновски). Скопје: Институт за старословенска култура, Прилеп - Книгоиздателство „Матица македонска”, 2000.

PMC: Речник сриискохрвайског̄a књижевног̄ језика, I-VI. Нови Сад: Матица српска, 1967-1976.

РСАНУ: Речник сриискохрвайског̄ књижевног̄ и народног̄ језика, 1-. Београд: Српска академија наука (и уметности) - Институт за српски (/ српскохрватски) језик, 1959-.

PCJ: Речник срйског̄а језика. Нови Сад: Матица српска, 2007.

СМ: Словенска мийолог̄ија. Енииклойедијски речник (ред. С. М. Толстој и Љ. Раденковић). Beograd: Zepter book world, 2001.

Станолевић, Станоје. Народна енииклойедија срйско-хрвайско-словеначка, I. Загреб 1925. Ср. Карловци - Нови Сад: Штампарија „Будућност”, Нови Сад - Издавачка књижарница Зорана Стојановића, 2001².

СтевАновић, Михаило и др. Речник језика Пейра II Пейровића Њег̄oщua, І. Београд - Титоград - Цетиње: Вук Караџић - Народна књига и др. 1983.

Херодойова Истиорија (прев. М. Арсенић). Београд: Дерета, 2009.

Цвилић, Јован. Балканско йолуосйрво, Сабрана дела, 2. Београд: Српска академија наука и уметности - Завод за уџбенике и наставна средства, $2000 \mathrm{a}^{3}$.

Цвијић, Јован. Говори и чланци, Сабрана дела, 3. Београд: Српска академија наука и уметности - Завод за уџбенике и наставна средства, 2000б․

ЧАЈкАновић, Веселин. О маг̃ији и религ̃ ији (ур. С. Велмар-Јанковић). Београд: Просвета, 1985.

ЧАлкановић, Веселин. Сабрана дела из срйске религ̄ије и митиолог̄ије, I: Сйудије из срйске религ̄ије и фолклора 1910-1924 (прир. В. Ђурић). Београд: Српска књижевна задруга, Београдски издавачко-графички завод, Просвета, Партенон М.А.М., 1994.

ШАркић, Срђан. Средњовековно срйско йраво. Нови Сад: Матица српска, 1995.

DANıčić, Gj. Poslovice. Zagreb, 1871. Београд: Међународни славистички центар на Филолошком факултету, 1996.

Grevs, Robert. Grčki mitovi (прев. B. Vein). Beograd: Familet, 2008.

Ivanov, Sergej. O poreklu karakačanske ovce i Karakačanima $<\mathrm{http} / /$ www.poljoberza.net/Autorski TekstoviJedan.aspx?ime=EF002_3.htm\&autor $=14>03.06 .2019$.

Mamuzı́, Ilija. Odjeci ilirizma (srpski i h̆hrvatski). Građa za povijest književnosti Hrvatske 32 (1978): 295-530.

Maretić, Tomo. Naša narodna epika. Beograd: Nolit, 1966.

MAteŠIć, Josip. Frazeološki rječnik hrvatskoga ili srpskoga jezika. Zagreb: IRO „Školska knjiga”, 1982.

Nodilo, Natko. Stara vjera Srba i Hrvata. Zagreb, 1885-1890. Split: Logos, 1981.

Oкика, Miloš. Srpski na kriznom putu (Povjesnica, ideologija, jezička zbilja). Istočno Sarajevo: Zavod za udžbenike i nastavna sredstva, 2006.

Papazoglu, Fanula. Srednjobalkanska plemena u predrimsko doba. Tribali, Autarijati, Dardanci. Skordisci i Mezi. Beograd: Equilibrium, 2007.

ReŠEtAR, Milan. Štokavski dijalekat (прев. S. Makočević). Podgorica: Matica crnogorska, 2010.

RJAZU: Rječnik hrvatskoga ili srpskoga jezika, I. Zagreb: Jugoslavenska akademija znanosti i umjetnosti, 1880-1882.

Siк IмIĆ, Biljana. Etnički stereotipi o Vlasima u Srbiji. Kulturni i etnički identiteti u procesu globalizacije i regionalizacije Balkana. Niš: Centar za balkanske studije - Junir, Punta, 2002, 187-203.

Sкок, Petar. Etimologijski rječnik hrvatskoga ili srpskoga jezika, III. Zagreb: Jugoslavenska akademija znanosti i umjetnosti, 1973.

Vlahović, Petar. Narodi i etničke zajednice sveta. Beograd: „Vuk Karadžić”, 1984.

Vlahović, Maja. Etnonim Vlah v srbohrvaščini in slovenščini. Slava IV/2 (1990): 144-156.

ŽARKović, Dragoljub. Šinobus za Niš. Od petka do petka <http://www.transparentnost.org.rs/stari/ ts_mediji/stampa/2005/12DECEMBAR/09122005.html> 17.01.2020. 
Prvoslav Radić

\author{
NOTES ON SERB PHRASEOLOGY: \\ (VIDETI) ČIJA MAJKA CRNU VUNU PREDE \\ Linguocultural approach
}

S u m m ary

The paper seeks to interpret the expression (videti) čija majka crnu vunu prede - lit. (to see) whose mother spins black wool. The analysis demonstrates that the deeper semantic structure of the expression is probably underlain by an image associated with the ethnically heterogeneous livestock breeding population of the Balkans, commonly referred to as the "vlasi" (cf. Vlachs). In this particular expression, they are referred to through metonymy - 'those who spin black wool, those who wear black woollen clothes'. Among the neighbouring permanently settled and less mobile communities, their nomadic lifestyle gave rise to many preconceptions and prejudices, primarily associated with their allegedly erratic and inconsistent nature. In this context, the meaning of the expression could easily be encapsulated as follows: 'an unreliable, unfaithful person', and in some contexts even as 'a traitor'.

The expression undoubtedly evolved, ramified and developed along equally complex lines over a long period, and then, with the waning of the socioeconomic matrix that had engendered it and the decline of the military patriarchy that had eagerly embraced it, it was inevitably sinking into obsolescence. As it is often the case, the process took the form of the suppression and obliteration of the main meaning, and an almost arbitrary grafting of new meanings. As a result, the meaning that is currently attributed to the expression is in fact the secondary, surrogate meaning, encapsulated in the figure of black wool as a sign of sorrow. Hence, in the Matica Srpska Dictionary, this expression is explained as follows: 'preparing the black garb as a sign of coming death'.

Универзитет у Београду

(Примљено: 23. марта 2020;

Филолошки факултет

прихваћено: 5. јуна 2020)

Студентски трг 3, 11000 Београд, Србија

prvoslavr@yahoo.com 